\title{
Greenland ice-margin programme, a pilot study at Pâkitsoq, north-east of Jakobshavn, central West Greenland
}

\author{
Henrik Højmark Thomsen, Ole B. Olesen, Roger J. Braithwaite \\ and Anker Weidick
}

A glaciological field programme was carried out from 24 July to 21 August 1988 on the Greenland ice-sheet margin at Pâkitsoq, north-east of Ilulissat/Jakobshavn, West Greenland. Glaciological investigations for planning hydropower at Pâkitsoq have been made by GGU since 1982. The investigations include six years of massbalance measurements, repeated photogrammetric and satellite mapping, ice-thickness mapping by radio-echo sounding, stable-isotope studies, hot-water-jet drillings and measurements of ice velocity and englacial temperatures (Thomsen, 1986, 1988; Thorning \& Hansen, 1987; Olesen \& Clausen, 1988). Simulations of runoff, glacier dynamics and glacier hydraulics are also carried out (Reeh, 1983; Thomsen et al., 1988). The aim of the 1988 field programme was to extend and confirm assumptions in the previous work.

GGÙs activities at Pâkitsoq combined with inland investigations along the EGIG-line (Expédition Glaciologique Internationale au Groenland) just north of the basin, make the area one of the best studied sectors of the Greenland ice sheet. This has attracted attention internationally, especially as a possible site for future studies of the greenhouse effect. In 1988, therefore, researchers from the Netherlands, West Germany, Switzerland and USA also took part in the field work in close cooperation with the GGU team.

The field programme consisted of a number of separate but integrated projects by the individual teams which were coordinated by GGU. Several smaller camps were established with a base camp as a centre located on the ice sheet $4.2 \mathrm{~km}$ east of the lake $S \varnothing 187$ at an elevation of $470 \mathrm{~m}$ a.s.l. (figs 1 and 2). The work was supported by a helicopter from Jakobshavn on an ad hoc charter and by a helicopter shared with the GGU Disko Bugt project based at Atâ (Kalsbeek, 1989).

\section{The participants and their work topics}

(1) C. E. Bøggild, R. J. Braithwaite, E. Hansen, O. B. Olesen, H. H. Thomsen, L. Thorning and A. Weidick (GGU): Mass-balance measurements, hot-water drilling, radar measurements, dye-tracer experiments and glacial geology; (2) A. Letréguilly, H. Oerter and N. Reeh (Alfred Wegener Institute for Polar Research, West Germany): Stable-isotope investigations, ice-ve- locity measurements; (3) C. Leibundgut and A. Gies (University of Bern, Switzerland): Dye-tracer experiments; (4) M. F. Meier and T. Pfeffer (University of Colorado, USA): Reconnaissance study of infiltration and refreezing in lower accumulation area; (5) J. Oerlemans (University of Utrecht, the Netherlands): Reconnaissance study for locating site for possible future energy-balance measurements. All external groups were self-financing except the team from the University of Bern who worked for GGU under contract.

\section{Mass-balance measurements 1987/88}

The stakes (fig. 1) established for mass-balance measurements in earlier years were visited by helicopter on 19 May and 18 August. Further stake readings were made with irregular intervals in August during the main field work. The winter snow cover on the ice was very patchy and confined mainly to drifts in gullies and crevasses up to an elevation of about $700 \mathrm{~m}$ a.s.l. but snow cover was continuous at higher elevation. The transient balance for the winter period was measured in snow pits and by depth sounding at the stakes. The snow surface showed signs of melting in May with water-soaked snow occupying depressions on the surface. However, little or no ablation occurred as there were no signs of drainage. Stake readings on 18 August show an annual equilibrium line at approximately $1050 \mathrm{~m}$ a.s. 1 .

\section{Hot-water drilling and borehole logging}

Hot-water drilling (fig. 2) was continued to investigate thermal and hydraulic conditions in, and beneath the ice, and for testing improvements of the drill. Eleven holes were drilled with a total length of $3220 \mathrm{~m}$. The drillings were concentrated around the base camp. Nine holes were drilled along a profile crossing a subglacial valley leading to the lake Sø 187 to investigate the hydraulic conditions in the ice. An improved clinometer and a device for weighing the load on the extended hose were tested. This combined system made it much easier to control the drilling and to decide when the bottom was reached. At some places penetration to the bottom of the ice was difficult because the drill had to penetrate several layers of ice with debris at different levels above 


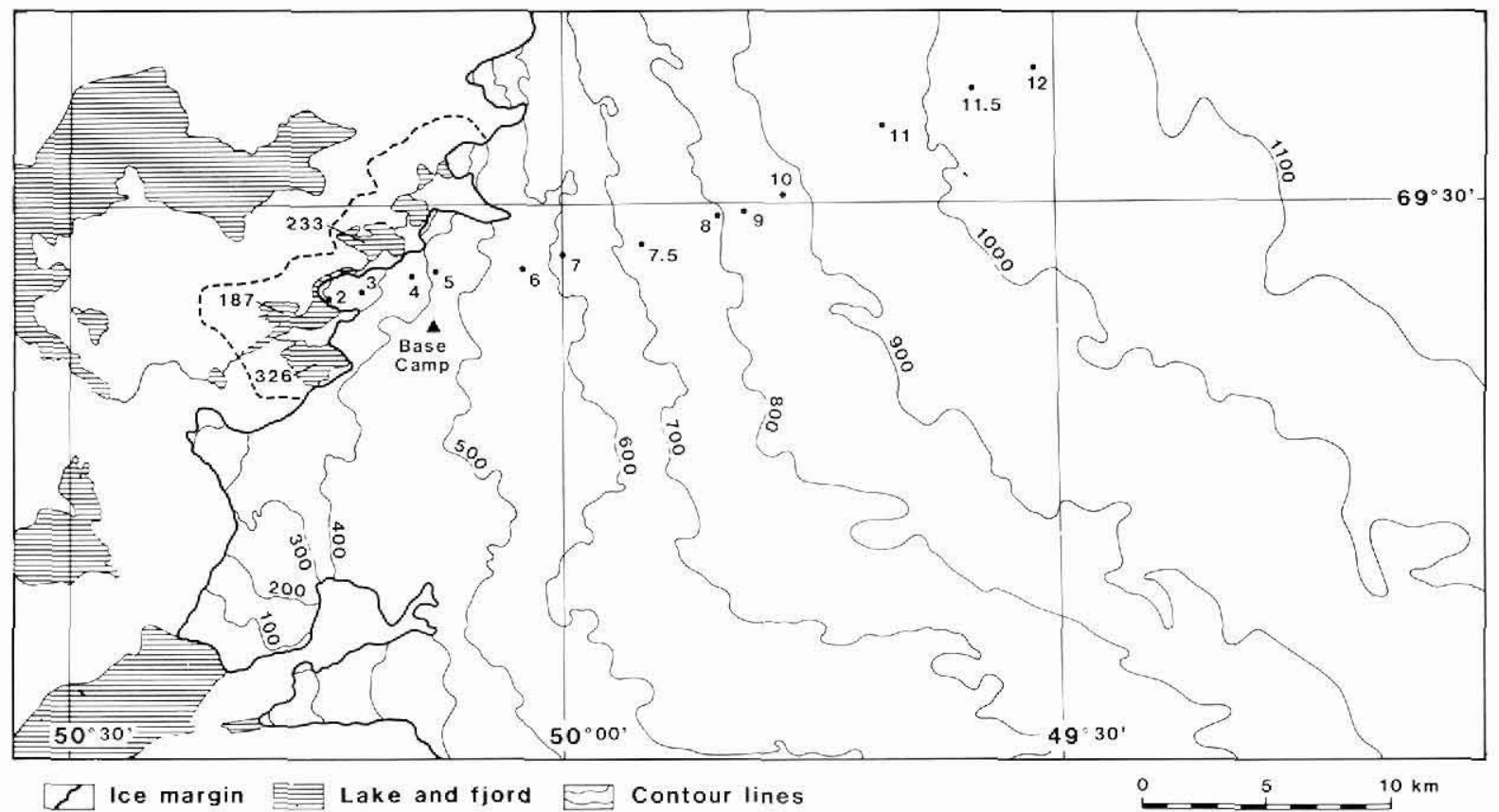

Fig. 1. Drainage basin at Pâkitsoq. Stakes for measuring mass balance are shown. Contours in metres.

the bedrock. Sudden drops of water level were observed in the drill holes during drilling, indicating the existence of voids or englacial conduits. Explosives were used for blasting at the bottom of the boreholes to force a possible connection to the hydraulic system at the bed. At one drill site the water level was standing at the ice surface when the drill reached the bottom, but dropped suddenly at the moment of blasting in the hole. In order to prevent freezing of the holes and to record piezometric water pressure over an extended period of time, the holes were drilled close to small surface streams which were led artificially to the holes. However, recording of water levels failed due to failures in the pressure sensors and freezing of holes despite the countermeasures. Attempts to enlarge the holes with different reamers were difficult and improvements are needed.

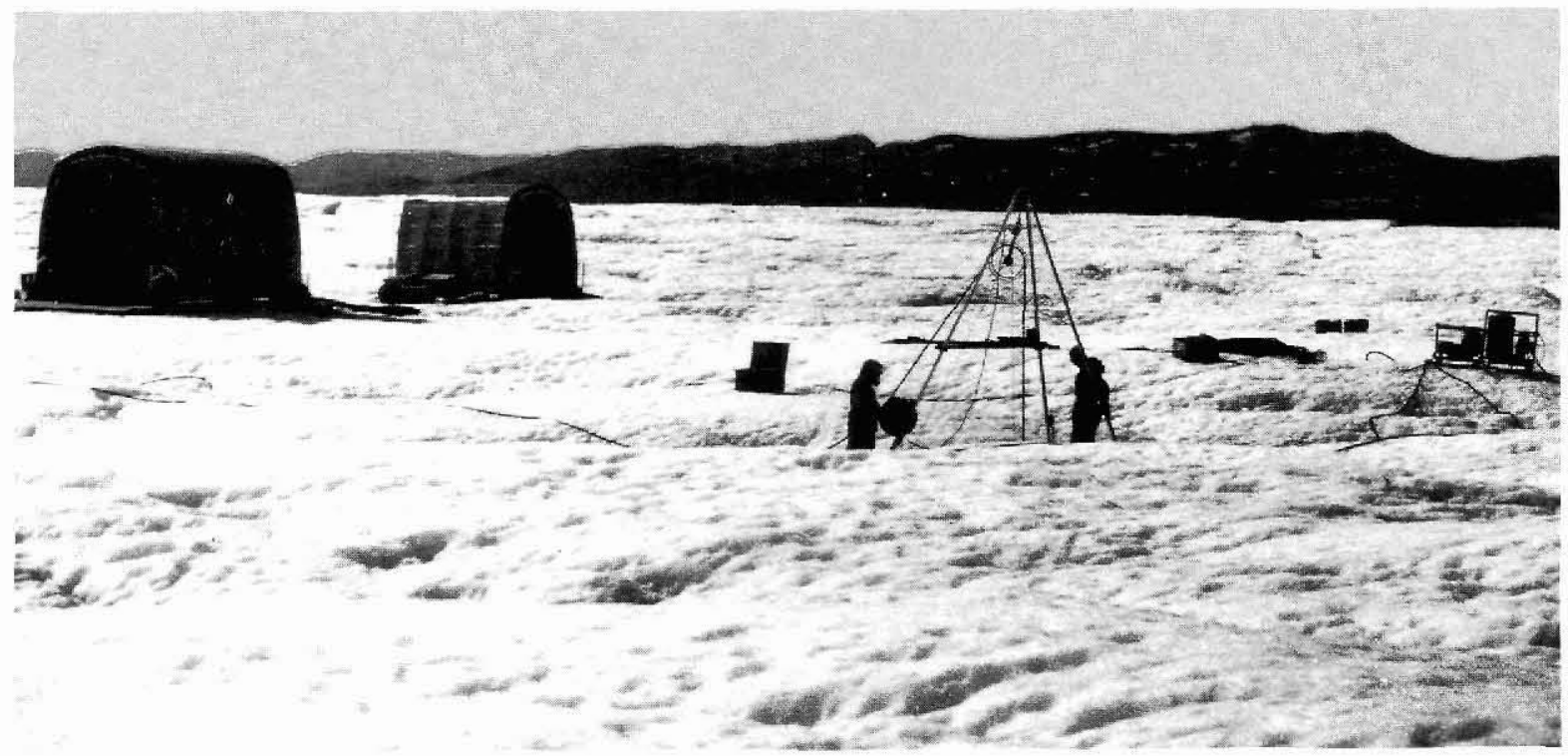

Fig. 2. Hot-water-jet drilling at base camp. 
The few readings in the holes indicate a high water pressure in agreement with the modelling by Thomsen et al. (1988) but it should be stressed that difficulties exist in interpreting the recordings, and further work is needed for conclusive statements.

\section{Englacial temperatures}

Thermistors mounted in the ice in 1987 were re-measured and showed a stable temperature pattern as described by Thomsen (1988). The temperatures are high compared to ice temperatures measured by deep drilling in the accumulation zone of the ice sheet (Gundestrup \& Lyle Hansen, 1984) suggesting an effective warming of the ice due to production of superimposed ice. Much lower temperatures are also reported from the ablation zone at Jakobshavn Isbræ, just south of the Pâkitsoq area where the ice movement is much faster (K. Echelmeyer, personal communication, 1988). To investigate this it was planned to drill more thermistors at Pâkitsoq in an array of bore holes inland from the ice margin. One thermistor string was drilled through the ice at stake 7 (fig. 1) but a second drilling at stake 11 was not carried through because the drill was accidentally dropped from a helicopter and destroyed.

\section{Dye-tracer experiments}

Artificial tracers were used for checking the results of the glacier hydraulic modelling in the basin (Thomsen $e t$ al., 1988), and for improving knowledge of the drainage system. The experiment was concentrated near the base camp in an area where the interpretation of model results is ambiguous. Three different fluorescent dyes were injected in the selected moulins: one moulin predicted to drain to the lake S $\varnothing 187$; one moulin lying over the predicted subglacial water divide separating water drainage to the lakes $S \varnothing 326$ and $S \varnothing 187$; one moulin which most likely drains water to $\$ \varnothing \mathbf{3 2 6}$ or, less likely, out of the basin to the big outlet glacier ending in the fjord south of the area (fig. 1). The natural setting of the Pâkitsoq basin makes dye-tracer experiments difficult. For example, the largest part of the meltwater drains to the ice-free land through deep lakes and the exact point of exit in the lakes is not known. The mixing of dyed water and lake water makes sampling difficult. Water samples were taken from a rubber dinghy near the ice margin, in $\mathrm{S} \emptyset 326, S \emptyset 187$ and in the fjord south of the basin, and were analysed with a portable fluorometer. The sampling was concentrated at locations where monopulse radar data indicated that it was most likely to find the subglacial water outlet in the lakes. The time for sampling at the different locations was decided by the flow times inferred from the modelling. The analyses of samples in the field suggest a drainage pattern described as the most likely by the modelling, but more detailed analyses of samples in the laboratory are necessary for confirmation, and to investigate peak tracer concentrations, cumulative tracer return and water-flow velocities providing a better understanding of the actual drainage system in and beneath the ice.

\section{Ice-thickness measurements}

Ice thickness was measured by monopulse radar for a more complete mapping of the subglacial terrain close to the ice margin. Improvements of the radar were tested and ice-thickness profiles were established on the glacier tongues ending in the lakes $\$ \emptyset 187$ and $\mathrm{S} \emptyset 326$, together with a profile where hot-water-jet drillings were carried out (Thorning \& Hansen, 1989).

\section{Isotope investigations, surface dating and velocity measurements}

Stable isotope investigations and conductivity measurements on surface ice, as well as ice-velocity measurements were carried out by the West German team to investigate the effects of past climate on the Greenland ice sheet (Reeh et al., 1989).

\section{Glacial geology}

The record of the early Holocene ice-margin recession over the West Greenland coastland, including the Pâkitsoq area, is well known. In contrast to this, the subsequent history of late Holocene oscillations in the position of the ice margin is nearly unknown, due to readvances causing the ice-margin deposits of the Holocene climatic optimum to be concealed under the present ice margin (Weidick, 1985).

Organic material (wood, shells and bones) is brought to the ice margin from these buried deposits, and so far age determinations of two wood fragments in the neoglacial moraines of the ice margin have given ${ }^{14} \mathrm{C}$ ages of $285 \pm 100$ B.P. (Weidick 1972, I-5418) and $120 \pm 55$ B.P. (Salix sp. collected 1985 by N. Reeh and H. H. Thomsen, identification by $\mathrm{O}$. Bennike, K-4571). This indicates a vegetation overridden by the latest Little Ice Age advance, the culmination of which here occurred at around A.D. 1880 according to historic records.

Of greater interest are two older dates, obtained on shells and bones from this locality. The first was made on a shell fragment of Mya truncata (sample collected 1961 by R. Beschel \& A. Weidick, identification A. Weidick) with a ${ }^{14} \mathrm{C}$ age of $3420 \pm 105$ B.P. (Ua-699) 
and bones of a reindeer (sample collected 1985 by $\mathrm{N}$. Reeh and H. H. Thomsen, identification N. Noe-Nygaard) with an age of $3040 \pm 60$ B.P. (K-4572).

In the summer of 1988 a systematic collection of organic material was extended from Pâkitsoq to other localities around Jakobshavn Isfjord, namely the southern flank of Jakobshavn Isbræ at $50^{\circ} 03^{\prime} \mathrm{W}, 69^{\circ} 08^{\prime} \mathrm{N}$ and Alangordliup sermia at $50^{\circ} 15^{\prime} \mathrm{W}, 68^{\circ} 56^{\prime} \mathrm{N}$ in the Christianshåb area. More samples are being dated and it is hoped that these combined with the present knowledge about the subglacial terrain will provide an estimate of the magnitude of the maximum retreat of the ice margin during the Holocene.

\section{Reconnaissance studies}

Participants from USA and the Netherlands carried out reconnaissances for future research on ice wastage in response to a greenhouse-induced climatic warming. Reconnaissance was made to the lower accumulation area by the American team to look at mass balance and runoff conditions. This included studies of superimposed ice formation, facies conditions in the wet-snow zone and percolation experiments with fluorescent dye in areas with different surface characteristics. Reconnaissance for possible future energy balance studies was made by J. Oerlemans. Aside from the scientific aspects the reconnaissances were also concerned with logistic conditions to select suitable future research locations.

\section{Outlook}

The investigations at Pâkitsoq can benefit and contribute to other planned and present projects in the area. For example, a Swiss glaciological programme is planned to investigate changes in ice margins caused by changes in water levels in reservoirs (Funk \& Röthlisberger, in press) with Pâkitsoq as a possible research location (Funk, personal communication, 1988). Wave gauges for monitoring calving waves were mounted in 1987 along the lakes Sø 187 and Sø 326 by H. Röthlisberger (Swiss Federal Institute of Technology) in connection with GGU's glaciological work. The dynamics of Jakobshavn Isbræ, which makes up the neighbouring ice sheet sector to the south of the Pâkitsoq basin, are being investigated (Echelmeyer \& Kamb, 1986) under a joint American-Swiss programme.

Acknowledgements. We thank Thorkild Thomsen (Greenland Technical Organisation) for use of camp facilities at Sø 187. Claus Kern-Hansen and Jens R. Valeur (Greenland Technical
Organisation) helped with sampling and logistics for the dyetracer experiments.

\section{References}

Echelmeyer, K. \& Kamb, B. 1986: Measurements of short period motion on a fast moving glacier and analysis of data. (Abstract.) Ann. Glaciol. 8, 204 only.

Funk, M. \& Röthlisberger, H. in press: Forecasting the effects of a planned reservoir that will partially flood the tongue of Unteraargletscher, Switzerland. Ann. Glaciol.

Gundestrup, N. S. \& Lyle Hansen, B. 1984: Bore-hole survey at Dye 3, South Greenland. J. Glaciol. 30(106), 282-288.

Kalsbeek, F. 1989: GGU's expedition in the Disko Bugt area, 1988. Rapp. Grønlands geol. Unders. 145 (this volume).

Olesen, O. B. \& Clausen, A. 1988: Test drilling with a hot water jet at the Inland Ice margin. Rapp. Gronlands geol. Unders. 140, 121-124.

Reeh, N. 1983: Ikke-stationær beregningsmodel for Indlandsisens randzone. Grønlands geol. Unders., Gletscher-hydrol. Meddr 83/7, 81 pp.

Reeh, N., Letréguilly, A. \& Oerter, H. 1989: Continued stable isotope studies on the Greenland ice-sheet margin at Pâkitsoq, north-east of Jakobshavn, central West Greenland. Rapp. Grønlands geol. Unders. 145 (this volume).

Thomsen, H. H. 1986: Is og vandkraft. Glaciologi i vandkraftprojektet bynære bassiner 1982-1986. Glaciology and hydropower. Glaciology for local hydropower projects, 19821986. Grønlands geol. Unders., Gletscher-hydrol. Meddr 86/2, 73 pp.

Thomsen, H. H. 1988: Mass balance, ice velocity and ice temperature at the Inland Ice margin north-east of Jakobshavn, central West Greenland. Rapp. Gronlands geol. Unders. 140, 111-114.

Thomsen, H. H., Thorning, L. \& Braithwaite, R. J. 1988 Glacier-hydrological conditions on the Inland Ice north-east of Jakobshavn/Ilulissat, West Greenland. Rapp. Grønlands geol. Unders. 138, map with text.

Thorning, L. \& Hansen, E. 1987: Electromagnetic reflection survey 1986 at the Inland Ice margin of the Pâkitsoq basin, central West Greenland. Rapp. Grønlands geol. Unders. $135,87-95$.

Thorning, L. \& Hansen, E. 1989: Measurements of ice thickness on glaciers at Isortuarssûp tasia, southern West Greenland and Pâkitsoq, central West Greenland. Rapp. Grønlands geol. Unders. 145 (this volume).

Weidick, A. 1972: $C^{14}$ dating of survey material performed in 1971. Rapp. Grønlands geol. Unders. 45, 58-67.

Weidick, A. 1985: Review of glacier changes in West Greenland. Z. Gletscherk. Glazialgeol. 21, 301-309.

H. H. T., O. B. O., R. J. B. \& A. W. Gronlands Geologiske Undersøgelse, $\emptyset$ ster Voldgade 10 $D K-1350$ Kфbenhavn $K$, Danmark 